http://dx.doi.org/10.18778/7969-144-9.22

MONIKA SULEJEWICZ-NOWICKA*

\title{
Oficyna wydawnicza E. Wendego na rzecz edukacji szkolnej na przykładzie serii „Wybór Pisarzów Polskich i Obcych dla Domu i Szkoły” i „Biblioteka Klasyków Polskich”
}

Seria wydawnicza1 to według Podręcznego słownika bibliotekarza wydawnictwo ciągłe składające się z indywidualnych tytułów o wspólnej nazwie dla całości, w której obrębie mogą, ale nie muszą być numerowane ${ }^{2}$. Wyróżniają ją znaki

* Dr, Biblioteka Uniwersytetu Łódzkiego, Oddział Opracowania i Uzupełniania Zbiorów, 90-237 Łódź, ul. Jana Matejki 32/38.

1 Seriom wydawniczym poświęcono kilkanaście prac. Najważniejsze z nich to: Katalog polskich wydawnictw seryjnych i biblioteczek szkolnych w układzie alfabetycznym według tytułów, Warszawa 1938; A. Morawska, Serie wydawnicze w Polsce Ludowej, Warszawa 1971; R. Cybulski, Serie książek kieszonkowych w Polsce w latach 1966-1970, Warszawa 1972; K. Rulka, Bibliofilskie wydawnictwo seryjne: Książki o książce, „Archiwa, Biblioteki, Muzea” 1972, t. 25, s. 251-264; J. Dunin, Rozwój cech wydawniczych polskiej książki literackiej XIX-XX wieku, Łódź 1982 (rozdz. X), s. 160-194); E. Mrzygłocka, Serie wydawnicze dla dzieci i młodzieży 1970-1982. Bibliografia, Warszawa 1985; A. Jędrych, Polskie serie literackie i paraliterackie 1901-1939, Łódź 1991; A. Jazdon, Wielkopolskie serie wydawnicze do 1945 roku, „Prace Biblioteki Uniwersyteckiej w Poznaniu” 1997, nr 2; G. Straus, K. Wolff, Czytać, nie czytać... kupować, nie kupować, Warszawa 2000; S. Kurek-Kokocińska, „Biblioteczka Aforystów" Państwowego Instytutu Wydawniczego, [w:] Od księgoznawstwa przez bibliotekoznawstwo do nauki o informacji XXI w., Białystok 2007, s. 91-116; J. Starnawski, Andrzej Baumfeld-Boleski i jego brat Gustaw, poloniści - przemyślanie, „Rocznik Przemyski” 2008, t. 44, z. 3, s. 85-100; M. Kowalska, Literackie serie wydawnicze w Polsce w latach 1921-1999, [w:] Dokąd zmierzamy? Książka i jej czytelnik. Materiały z ogólnopolskiej konferencji naukowej zorganizowanej przez Bibliotekę Główną Uniwersytetu Szczecińskiego, Międzyzdroje, 20-22 września 2007, red. R. Gaziński, Szczecin 2008, s. 109-126; U. Kowalewska, Rola polskich serii książkowych na przykładzie serii państwowego wydawnictwa "Iskry” w latach 1956-1992, „Acta Universitatis Lodziensis” 2009, Folia Librorum”, nr 15, s. 101-117; B. Kuć, Seria wydawnicza „Książnica Tłumaczeń Łacińskich”, „Acta Universitatis Lodziensis" 2010, Folia Librorum", nr 16, s. 159-170.

2 Hasła Seria, Wydawnictwo seryjne w: Podręczny słownik bibliotekarza, oprac. G. Czapnik, Z. Gruszka, przy współpracy H. Tadeusiewicz, Warszawa 2011, s. 303. 
identyfikacyjne, do których zalicza się: tytuł serii, numer tomu, znak graficzny, tematyka, format i ukształtowanie druku³. Serializacja zaś, jak słusznie zauważył Janusz Dunin, była jednym z najważniejszych odkryć w dziedzinie popularyzacji książki [...]. Już dawno stwierdzono, że jeśli czytelnik był zadowolony z jakiejś książki, poszukiwał podobnej"4.

Literackie wydawnictwa seryjne z początku XX wieku adresowane do młodzieży szkolnej to bogaty materiał badawczy. Ich wydawcy, okoliczności powstania, zakres tematyczny, opracowanie językowo-stylistyczne oraz przygotowanie edytorskie i redakcyjne to zagadnienia wymagające szerszego omówienia. Trzeba pamiętać, że w latach 1900-1939 ukazywało się ok. sześciuset literackich serii ${ }^{5}$. Określając natomiast w szerszym aspekcie odbiorców dawnych wydawnictw seryjnych jako „młodzież szkolną”, należy zaznaczyć, iż w kręgu zainteresowań tak zdefiniowanego adresata winny się znaleźć podręczniki, repetytoria, bryki czy podręczne źródła z danej dziedziny, a więc z: ekonomii, historii literatury polskiej i obcej, historii Polski i historii powszechnej, techniki czy też nauk przyrodniczych. Z kolei z punktu widzenia badacza serii literackich przedmiotem rozważań powinny być utwory poetyckie, prozatorskie czy dramatyczne z zakresu literatury pięknej polskiej i obcej zalecane przez podręczniki oraz wszelkiego rodzaju programy i wypisy szkolne czy wskazówki metodyczne i dydaktyczne. Na początku XX wieku kładziono szczególny nacisk na naukę języka polskiego. W tym też czasie nasiliło się oddziaływanie polskiej książki. Miały w tym swój udział gazety, na łamach których ukazywały się hasła zachęcające do czytania oraz utwory w odcinkach. Wiadomo było, że jednym z oręży w walce o ojczyznę i zachowanie ducha narodu jest krzewienie polskiej literatury i historii za pomocą właśnie druku. Dlatego też propagowaniem czytelnictwa zajmowały się legalne i tajne biblioteki ${ }^{6}$. W dydaktyce zaś wychodzono z założenia, że obcowanie z tekstami literackimi to nie tylko obcowanie z językiem, tudzież językiem narodowym, ale to „podstawa myślenia w ogóle, podkład całej wiedzy, bo tylko umiejąc układać logicznie w głowie i wypowiadać nabyte wiadomości, możemy zdobywać wiedzę, tylko czytając ze zrozumieniem, możemy zacząć ją zdobywać"7. Książce wyraźnie przypisywano funkcję wychowawczą, obok popularyzacyjnej i poznawczej, o czym niejednokrotnie pisali $w$ artykułach metodycznych i dydaktycznych wydawcy omawianych serii ${ }^{8}$. Podobne treści niosła przedmowa do serii „Wybór Pisarzów Polskich i Obcych dla Domu i Szkoły". Jej redaktorzy wyraźnie podkreślali, że ich celem jest stworzenie takiego wydawnictwa, które mogłoby stanowić podstawo-

${ }^{3}$ J. Dunin, Rozwój cech wydawniczych polskiej książki literackiej XIX i XX wieku, Łódź 1982, s. 160.

4 Tamże, s. 160.

5 Tamże, s. 175.

6 J. Wróblewski, Rola książki polskiej w kształtowaniu się świadomości narodowej w okresie zaborów (1795-1918), „Rocznik Biblioteki Narodowej” 1989, R. 25, s. 189-211.

7 M. Tańska, Uwagi metodyczne przy nauczaniu języka polskiego, [w:] Programy szkolne i uwagi metodyczne, zebrała i ułożyła taż, Warszawa 1915, s. 5.

${ }^{8}$ A. Baumfeld, Współczesna literatura polska w szkole średniej, „Nowe Tory” 1911, z. 4, s. 441-449.

„[...] literatura powinna wychowywać, ku temu potrzebne są teksty literackie” (s. 442). 
wy księgozbiór obywatela - w domyśle młodego obywatela - „mieszczący twory najlepszych pisarzów narodowych, i dzieła, objaśniające przeszłość i stan obecny narodu". Będące przedmiotem analizy wydawnictwa seryjne jasno wskazywały wyraźny adres wydawniczy - młodzież szkolną. Ukazywały się z myślą właśnie o tych odbiorcach literatury.

Serie „Wybór Pisarzów Polskich i Obcych dla Domu i Szkoły” i „Biblioteka Klasyków Polskich” (tudzież „Wendego Biblioteka Klasyków Polskich”) wychodziły spod prasy drukarskiej w burzliwym okresie, obfitującym w ważne wydarzenia na polskiej i międzynarodowej scenie politycznej, które ruchowi wydawniczemu nie sprzyjały. Dla pierwszej wymienionej serii były to lata 1907-1923 (27 tytułów), zaś dla drugiej 1913-1921 (9 tomów). Wówczas w latach 1901-1918, jak wynika z badań Artura Jazdona, na terenie samej Wielkopolski ukazywały się 62 wydawnictwa seryjne ( 2 z nich stanowiły kontynuację), a w sumie zarejestrowano ok. 4000 tytułów9 . Warto zaznaczyć, że tradycje szkolnych wydawnictw seryjnych nie były długie. Za pierwszą taką serię uznaje się „Zebrania rytmów, przez wierszopisów żyjących lub naszego wieku zeszłych pisanych" Andrzeja Załuskiego wychodzącą w latach 1752-1756 ${ }^{10}$. Kolejną był „Wybór Celniejszych Pisarzów Polskich" Tadeusza Mostowskiego, który ukazywał się w latach 1803-180811. Chociaż adresatem tej serii niezupełnie była młodzież ucząca się, to jednak wykorzystywano ją do użytku szkolnego. Posługiwał się nią np. Adam Mickiewicz, który będąc na posadzie nauczyciela w Kownie, sprowadził ją nawet do tamtejszej

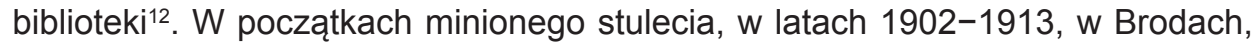
w oficynie Feliksa Westa, wychodziło wydawnictwo ciągłe o wyraźnie szkolnym profilu, a mianowicie „Arcydzieła Polskich i Obcych Pisarzy”. Seria ta liczyła blisko sto tomów. Wydano w niej dzieła m.in. Cycerona, Eurypidesa, Sofoklesa, Schillera, Byrona, Kochanowskiego, Skargi, Krasickiego, Brodzińskiego, Felińskiego, Zabłockiego, Fredry, Mickiewicza, Słowackiego, Krasińskiego, Goszczyńskiego, Kraszewskiego. Opracowaniem i przygotowaniem tekstów do edycji wraz z objaśnieniami zajmowali się badacze literatury, przede wszystkim: Wiktor Hahn, Tadeusz Pini, Piotr Chmielowski, Bohdan Łepki, Kazimierz Zimmermann. Przygotowany pod względem edytorskim utwór poprzedzał wstęp, na który składały się: biografia autora, streszczenie prezentowanego dzieła oraz charakterystyka pierwszoplanowych postaci.

„Wybór Pisarzów Polskich i Obcych dla Domu i Szkoły” wychodził w latach 1907-1924. Cena poszczególnych tomów wahała się od 15 do 25 kopiejek. Nazwa tej serii początkowo brzmiała „Wybór Pisarzów dla Domu i Szkoły”. W 1916 roku została przekształcona i doprecyzowana o pisarzów „polskich i obcych”. Jej redaktorami byli badacze literatury z najważniejszych wówczas ośrodków naukowych: Bronisław Chlebowski (Uniwersytet Warszawski, Towarzystwo Naukowe

\footnotetext{
9 A. Jazdon, Wielkopolskie serie..., s. XII.

10 A. Morawska, Wstęp, [w:] Serie wydawnicze..., s. XV.

11 Hasło Seria w: Encyklopedia wiedzy o książce, red. nacz. A. Birkenmajer, B. Kocowski, J. Trzynadlowski, Wrocław-Warszawa-Kraków 1971, s. 2148.

12 Za tę cenną informację dziękuję prof. Jerzemu Starnawskiemu.
} 
Warszawskie), Ignacy Chrzanowski (Uniwersytet Jagielloński, Polska Akademia Umiejętności) i Henryk Galle (Towarzystwo Naukowe Warszawskie). Wszyscy trzej redaktorzy mieli liczne zasługi na polu polskiej dydaktyki. Każdy z nich praktykował i nauczał młodzież szkolną. Doświadczenia redaktorskie wyraźnie łączyli z działalnością pedagogiczną. Bronisław Chlebowski zajmował się historią literatury polskiego odrodzenia, baroku i romantyzmu. Opracował m.in. metodologię badania dziejów literatury narodowej z uwzględnieniem różnic terytorialnych i etnicznych oraz historię literatury XIX wieku (Literatura polska 1795-1905 jako główny wyraz życia narodu po utracie niepodległości, 1923). Z kolei Ignacy Chrzanowski opracował syntezę dziejów polskiej literatury od czasów najdawniejszych do końca XVIII wieku. Henryk Galle zaś był autorem podręcznika do nauki języka polskiego - Stylistyka i teoria literatury (1904). Opracowanie to wykorzystywano w klasie poprzedzającej systematyczny kurs historii literatury polskiej przed I wojną światową w gimnazjach ${ }^{13}$. Galle związany był także $z$ innymi wydawnictwami seryjnymi, tj. „Książki dla Wszystkich”, „Biblioteczka Narodowa”, „Arcydzieła Literatury Wszechświatowej” i „Biblioteka Dzieł Wyborowych”. Omawiana seria wychodziła nakładem Gebethnera i Wolffa, największej polskiej firmy księgarsko-wydawniczej drugiej połowy XIX i pierwszej XX w. Pojawienie się na rynku wydawniczym niniejszej serii szkolnej uwarunkowane było ówczesnymi realiami. Po walce o polską szkołę w rewolucji 1905 roku masowo zaczęły się ukazywać wszelkiego rodzaju podręczniki szkolne (stanowiły one ponad $50 \%$ ogólnopolskiej produkcji), broszury oświatowe, wydawnictwa seryjne i bryki, które były odpowiedzią na zapotrzebowanie publiczności literackiej ${ }^{14}$. Władze rosyjskie zezwoliły nie tylko na wprowadzenie języka polskiego do szkół elementarnych, ale pozwoliły na zakładanie organizacji oświatowych (najważniejszą była Polska Macierz Szkolna), bibliotek oraz prywatnych szkół z wykładowym językiem narodowym ${ }^{15}$.

Z kolei „Biblioteka Klasyków Polskich” ukazywała się w latach 1913-1921 w wydawnictwie Edwarda Wendego założonym wspólnie z Ferdynandem Hoesickiem w 1858 roku w Warszawie, ostatecznie sprzedanym w 1912 roku Ludwikowi Fiszerowi, a działającym jeszcze przez szesnaście lat ${ }^{16}$. Serię tę redagował Konrad Drzewiecki, do którego w 1914 roku dołączył Andrzej Baumfeld-Boleski ${ }^{17}$. To bardzo ważne i znaczące postaci dla tradycji edycji szkolnych. Byli to jedni z cenniejszych komentatorów literatury polskiej. Drzewiecki w 1914 roku opublikował Zarys metodyki języka polskiego. Była to pierwsza tego typu praca na gruncie dydaktyki polskiej ${ }^{18}$. Boleski z kolei napisał kilka artykułów o tematyce dydaktycznej, co miało istotny wpływ na kształt omawianego wydawnictwa seryjnego ${ }^{19}$.

13 J. Starnawski, Galle Henryk Ludwik, [w:] Słownik badaczy literatury polskiej, t. 3, red. tenże, Łódź 2000, s. 106.

${ }_{14}$ I. Wojsz, Gebethner i Wolff - największa polska firma księgarsko-wydawnicza drugiej połowy XIX i pierwszej XX w., „Rocznik Warszawski” 2002, R. 30, s. 164.

15 M. Pawlak, Zarys dziejów oświaty. Skrypt, Bydgoszcz 2007, s. 107.

16 Wende Edward (1830-1916), [w:] Encyklopedia..., s. 2446.

17 J. Starnawski, Andrzej Baumfeld-Boleski..., s. 86.

18 J. Starnawski, Drzewiecki Konrad Mieczysław, [w:] Słownik badaczy..., t. 5, s. 88.

$19 \mathrm{Na}$ ten fakt zwrócił uwagę J. Starnawski. Por. Andrzej Baumfeld-Boleski..., s. 88-89. 
Zwracając uwagę na strukturę omawianych serii, ich język, przygotowanie od strony edytorsko-redakcyjnej, należy zaznaczyć, iż pomimo faktu, że w „Bibliotece Klasyków Polskich” ukazało się tylko 9 tomów, to jednak na tle „Wyboru Pisarzów Polskich i Obcych dla Domu i Szkoły" wypada ona znacznie lepiej.

„Wybór Pisarzów Polskich i Obcych dla Domu i Szkoły” to seria o formacie $16^{\circ}, 17 \mathrm{~cm}$, numerowana, licząca 27 tomów. Miała nie tylko jednolity format, ale i jednolite opracowanie graficzne. Jak wskazuje sama nazwa, do wydawnictwa włączono autorów zarówno polskich (tj. Jan Kochanowski - Treny, t. 1; Odprawa posłów greckich, t. 3; Adam Mickiewicz - Grażyna, t. 2; Konrad Wallenrod, t. 4; Dziady część 2 i 4 tudzież fragmenty pośmiertne, t. 7; Kazimierz Brodziński - Wiesław, t. 5; Zygmunt Krasiński - Nie-Boska komedia, t. 8; Irydion, t. 12; Wincenty Pol - Mohort, t. 9; Antoni Malczewski - Maria, t. 10; Juliusz Słowacki - Lilla Weneda i Grób Agamemnona, t. 11; Beniowski, t. 18; Julian Niemcewicz - Powrót posła, t. 13; Alojzy Feliński - Barbara, t. 15; Ignacy Krasicki - Myszeis, t. 16; Mikołaja Doświadczyńskiego przypadki, t. 22; Pan Podstoli, t. 23; Franciszek Zabłocki - Sarmatyzm, t. 17; Wacław Potocki - Wojna chocimska; t. 19; Seweryn Goszczyński - Zamek kaniowski, t. 20; Mieczysław Romanowski - Dziewczę z Sącza, t. 21;), jak i obcych (Homer - lliada, t. 24; Owidiusz - Przemiany, t. 25; Horacy - Wybór poezji, t. 26 i 27). Co ważne, poszczególne utwory opracowywali nie tylko redaktorzy serii, chociaż w ich przygotowaniu znalazła się większość tomów wydawnictwa - Henryk Galle opracował tomy: 2, 4, 5, 8, 12, 15, 17, 21, a Bronisław Chlebowski: 6, 9, 13, 16, 22, 23. Ponadto opracowaniem zajęli się również: Gabriel Korbut, który zredagował tomy 10, 20, 25; Aureli Drogoszewski - 18 i Jan Zakrzewski - 24. Wydawnictwo seryjne objęło różne okresy literackie w dziejach historii literatury, począwszy od antyku, poprzez okres staropolski i oświecenie, a na romantyzmie skończywszy, z pominięciem czasów współczesnych. Znacznie mniejszy nacisk położono na przybliżenie młodemu czytelnikowi trudnej polskiej szesnasto- i siedemnastowiecznej literatury dawnej. W tym przypadku przywołano najważniejszego jej twórce - Jana Kochanowskiego - mistrza języka poetyckiego i „pierwszego artystę świadomego”20, który „stworzył poezję polską z niczego”21. Przedrukowując teksty oświeceniowe, wydawcy sięgnęli po Krasickiego, uważanego wówczas za doskonale odbijającego "ducha wieku" zwolennika poetyki francuskiej, ale nie jej ślepego naśladowcę, zachęcającego do czytania świetnym humorem oraz czyniącego język ojczysty „płynnym i dźwięcznym”22. Zabłockiego z kolei włączyli do serii ze względu na udane próby przeróbek sztuk francuskich, głównie Romagnésiego. Z kolei z twórczości Felińskiego nieprzypadkowo wybór padł na Barbare, albowiem uchodziła za „najlepszy utwór dramatyczny w całym tym okresie"23 jako „typowa sztuka francusko-klasyczna”24. Oczywiście z epoki romantyzmu nie mogło zabraknąć narodowych wieszczów. Wydawcy, drukując zarówno powieść poetycką, poematy, utwory liryczne, jak i dramaty romantyczne,

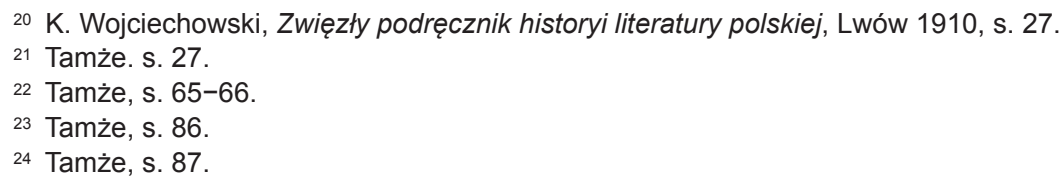


postarali się o przekrój: twórczości Mickiewicza, w której odbijała się „dusza narodu” 25 i z którą „weszliśmy w Europę, stanęliśmy w rzędzie narodów, które mogą poszczycić się geniuszami"26; Słowackiego, którego uznawano za mistrza formy i języka umiejącego „oddać najsubtelniejsze tony i półtony uczuć”27 oraz Krasińskiego, którego Nie-Boską komedię i Irydiona uznawano za „arcydzieła stylu”28. Redaktorzy większy nacisk położyli wyraźnie na te utwory, które w różnorodny sposób odnosiły się do sytuacji politycznej, a więc nawiązywały do powstania listopadowego, niewoli i upadku narodu oraz ukazywały sens dziejów narodowych. Dlatego też wśród postaci poszczególnych tekstów literackich, młodzież szkolna znalazła m.in. bohaterów, którzy poświęcali się walce z wrogiem dla dobra ojczyzny, sięgając nierzadko po naganne moralnie środki czy kierując się nieszlachetnymi motywami. Nie zabrakło również wątku romantycznej miłości oraz motywów autotematycznych, czyli refleksji nad samą sztuką poetycką. Z twórczości Pola redaktorzy wybrali uznawaną wówczas za najlepszą z jego gawęd, a więc Mohorta, zaś z Romanowskiego powieść poetycką Dziewczę z Sącza. Warto zaznaczyć, że o ile redaktorzy pokazali przekrój literatury polskiej i klasykę literatury powszechnej, o tyle poszczególnych autorów $\mathrm{i}$ ich dzieł nie wydawali jednak w porządku chronologicznym. Po drugie, poszczególnym twórcom poświęcono więcej niż jeden tom. Być może wydawcom przyświecała tzw. metoda koncentryczna, zalecana wówczas w programach metodycznych, polegająca najpierw na przyswajaniu najważniejszych wiadomości, a później ich utrwalaniu i rozszerzaniu. Można powiedzieć, że z jednej strony było zapotrzebowanie publiczności literackiej na kolejne dzieła poszczególnych autorów, z drugiej zaś młodzi czytelnicy, poznając jedno z dzieł danego twórcy, byli niejako gotowi na zapoznanie się z jego kolejnym tekstem, niekiedy znacznie trudniejszym w odbiorze ${ }^{29}$, chociaż niewątpliwie zakłócenie ciągłości chronologicznej z dzisiejszego punktu widzenia mogło wprowadzać chaos. Niemniej taką metodę zalecał m.in. redaktor drugiej z omawianych serii - „Biblioteki Klasyków Polskich”. Andrzej Boleski zauważył, że młodzież szkolną należy najpierw zapoznać z bliższymi oraz jednocześnie bardziej jej znanymi i najpoczytniejszymi autorami i ich dziełami, jak np. z Mickiewiczem czy Słowackim, by zaciekawić ją „zagadnieniem: jak wyglądała do tych czasów literatura, która tak szczytne dała owoce? Jak się rozwijała, zanim ów szczyt osiągnęła?" ${ }^{30}$. Wydawca uważał, że chronologicznej historii literatury należy nauczać studentów. Natomiast priorytetem jest wybór właściwej lektury.

Z kolei „Biblioteka Klasyków Polskich” pod redakcją Edwarda Wendego to wydawnictwo seryjne o formacie $16^{\circ}, 19 \mathrm{~cm}$, co prawda nienumerowane na stronie tytułowej, ale numeracja poszczególnych tomów pojawia się $w$ ich zestawieniu $\mathrm{w}$ ciągu liczbowanym wraz $\mathrm{z}$ tekstem literackim, jego autorem i informacją o redaktorze przygotowującym dany tom na rewersie karty przedtytułowej. Seria

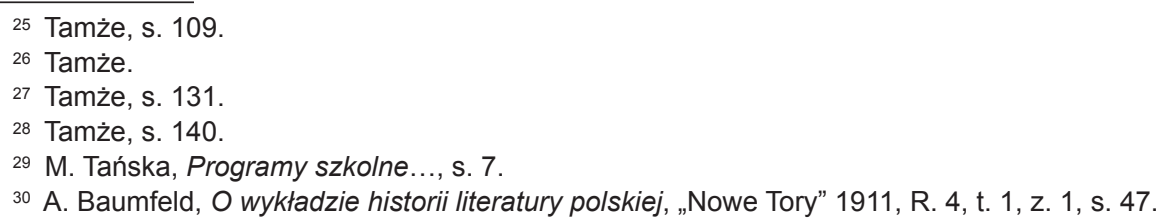


w sumie liczyła tylko 9 tomów. Posiadała jednolite opracowanie graficzne. Wydano w niej, jak sama nazwa wskazuje, „klasyków polskich” z XVI i XVII wieku, a więc skupiono się jedynie na literaturze dawnej. Wśród „klasyków” znaleźli się kolejno: Jan Kochanowski (Pisma polskie wybrane), Mikołaj Rej (Wybór pism wierszem i prozą), Sebastian Klonowic (Flis, Worek Judaszów i inne pisma polskie w wyborze), Łukasz Górnicki (Dworzanin polski, Rozmowa o elekcyjej i Dzieje w Koronie Polskiej w wyborze), Mikołaj Sęp Szarzyński (Rytmy abo wiersze polskie w wyborze), Andrzej Frycz Modrzewski (O naprawie Rzeczypospolitej z przekładu Cypriana Bazylika (r. 1577). Wybór), Szymon Szymonowic (Sielanki wybrane i Lutnia rokoszańska), Stanisław Orzechowski (Rozmowa albo dyjalog ok. egzekucyjej Polskiej Korony i Quincunx w wyborze), Wespazjan Kochowski (Psalmodia polska, Pieśń Wiednia wybawionego, Liryki wybrane). Trzy pierwsze i trzy ostanie tomy opracował Andrzej Boleski, natomiast czwarty, piąty i szósty Konrad Drzewiecki. Wydawcy skupili się zarówno na twórczości refleksyjnej, filozoficznej, miłosnej i sielskiej, jak i na prezentacji literatury politycznej wieków dawnych, wprowadzając do obiegu czytelniczego najznakomitszych poetów XVI i XVII wieku oraz jednych z najwybitniejszych publicystów wieków dawnych. Priorytetem było również przedstawienie tych „klasyków” literatury staropolskiej, których dzieła zachwycały nie tylko formą, ale i stylem i językiem. Ten zaś opatrzony odpowiednimi objaśnieniami stawał się zrozumiały dla młodzieży szkolnej. Jeden tom obejmował wybór z dzieł jednego staropolskiego autora.

W obu seriach część dzieł poszczególnych autorów wydawano w całości, a część we fragmentach, w tzw. wyborze. Była to metoda powszechnie stosowana, zalecana przez wypisy metodyczne i podręczniki, a praktykowana podczas konstruowania dawnych szkolnych wydawnictw seryjnych. W „Wyborze Pisarzów Polskich i Obcych dla Domu i Szkoły" w całości ukazały się m. in: Treny i Odprawa posłów greckich Kochanowskiego, Grażyna, Konrad Wallenrod i Dziady część 2 i 4 tudzież fragmenty pośmiertne Mickiewicza, Wiesław Brodzińskiego, Maria Malczewskiego, Lilia Weneda, Grób Agamemnona Słowackiego, Mohort Pola, Powrót posła Niemcewicza, Barbara Felińskiego, Myszeis Krasickiego, Sarmatyzm Zabłockiego, Zamek kaniowski Goszczyńskiego, Dziewczę z Sącza Romanowskiego. Natomiast w „Bibliotece Klasyków Polskich” tylko Pieśń świętojańska o sobótce, Treny, Odprawa posłów greckich, Muza i Satyr Kochanowskiego oraz Lutnia rokoszańska Szymonowica ${ }^{31}$.

Wszelkiego rodzaju zalecenia metodyczne i wypisy czy też obowiązujące wówczas podręczniki kształtowały omawiane wydawnictwa. Serie podążały właśnie za Historyją literatury niepodległej Polski (1906) Ignacego Chrzanowskiego, jednego z redaktorów pierwszej z serii prezentowanych wydawnictw, Zwięzłym podręcznikiem historyi literatury polskiej (1906), Wypisami polskimi dla szkół średnich (1922) i Wielkimi pisarzami polskimi. Wypisami na klasę VII szkół powszechnych (1923) Konstantego Wojciechowskiego, Wypisami polskimi dla szkół średnich Franciszka Próchnickiego i Konstantego Wojciechowskiego (1911) oraz za Wypisami polskimi dla klas wyższych szkół średnich współredagowanymi przez

31 Strukturę i kształt każdego tomu „Biblioteki Klasyków Polskich” omawia J. Starnawski w pracy Andrzej Baumfeld-Boleski..., s. 88-93. 
Chrzanowskiego i Wojciechowskiego (1917; znacznie szerszym opracowaniem niż wypisy autorstwa samego Wojciechowskiego). To właśnie te podręczniki i wypisy ustaliły obowiązujący kanon lektur, który z kolei respektowały prezentowane wydawnictwa seryjne. „Wyborowi Pisarzów Polskich i Obcych dla Domu i Szkoły" mimo wszystko bliższy był skrócony przez Konstantego Wojciechowskiego podręcznik do historii literatury polskiej oraz samodzielne wypisy tegoż autora i te, które współredagował wraz z Ignacym Chrzanowskim. Natomiast „Biblioteka Klasyków Polskich” respektowała kanon twórców i dzieł wskazany przez opracowanie Chrzanowskiego, czyli Historyję literatury niepodległej Polski. Obok strony redakcyjno-edytorskiej i wstępu krytycznego jest to kolejny atut tej serii, stawiający ją znacznie wyżej niż „Wybór Pisarzów Polskich i Obcych dla Domu i Szkoły". Trzeba zaznaczyć, że wydawcy mieli nieco odmienne poglądy na nauczanie literatury. Jednego z redaktorów „Wyboru Pisarzów Polskich i Obcych dla Domu i Szkoły", właśnie Ignacego Chrzanowskiego - autora obowiązującego wówczas podręcznika - ostro skrytykował redaktor „Biblioteki Klasyków Polskich”. Andrzej Boleski zarzucał przede wszystkim złą formułę opracowania, w którym znalazły się zbyt ogólnikowe dla ucznia informacje o danym autorze, albowiem „synteza winna być zdobywana przez uczniów samych" w trakcie poznawania materiału, a więc poszczególnych utworów literackich ${ }^{32}$. Do tego wychodził z założenia, że korzystniejsze dla młodego odbiorcy będzie zaprezentowanie mu całego Żywota Mikołaja Reja niż jego fragmentów, nawet jeśli dzięki takiemu okrojeniu materiału, wśród lektur mieliby się znaleźć chociażby Andrzej Frycz Modrzewski i Łukasz Górnicki ${ }^{33}$. Boleski jasno sformułował zasady nauczania: rozpoczynanie od utworów łatwiejszych oraz nieuwzględnianie porządku chronologicznego, ale tematyczny ${ }^{34}$. Co ważne podręcznik Ignacego Chrzanowskiego skrócił Konstanty Wojciechowski i w tym samym roku, 1906, opublikował Zwięzły podręcznik historyji literatury polskiej. Autor skupił się na podaniu odbiorcy krótkich informacji biograficznych o danym autorze i bardzo zwięzłym omówieniu jego poszczególnych dzieł. Tak zaprezentowany materiał niewątpliwie trafiał do młodego odbiorcy.

Warto podkreślić, że wydawcy omawianych serii skupili się nie tylko na podaniu młodemu odbiorcy tekstu literackiego. Prezentowany w danym tomie serii „Wybór Pisarzów Polskich i Obcych dla Domu i Szkoły” utwór poprzedzała krótka notka o autorze i jego dziele, podająca skąpe informacje biograficzne, ogólnikową genezę dzieła, bardzo pobieżne, na pewno nie krytyczne, jego omówienie oraz równie pobieżne wprowadzenie w tło kulturowe, historyczne i niekiedy literackie epoki. Znajdowały się w niej również, choć niekonsekwentnie, bo nie przy wszystkich tomach, informacje o tzw. podstawie wydania. Wydaje się, że tak drobiazgowe informacje edytorskie mogły być istotne dla redaktorów bądź bardziej wymagających odbiorców, jak chociażby studentów, ale nie dla młodzieży szkolnej. Młodzieży z pewnością przydałoby się bardziej krytyczne i drobiazgowe omówienie, niekoniecznie streszczenie. Niemniej serię tę można określić jedynie

\footnotetext{
${ }^{32}$ A. Baumfeld, O wykładzie historii..., s. 44-45 (cytat na str. 45).

${ }^{33}$ Tenże, O wykładzie historii literatury polskiej II, „Nowe Tory” 1911, z. 2, s. 139.

${ }_{34}$ Tamże, s. 140.
} 
wstępnym wydawnictwem ciągłym adresowanym do młodzieży szkolnej; wstępnym, bo dopiero wprowadzającym takiego odbiorcę w lekturę. W tym miejscu należy zaznaczyć, że redaktor drugiej z omawianych serii - Andrzej Boleski - zalecał unikanie „wiwisekcji utworów” na rzecz szczegółowych, dokładnych objaśnień, które miałyby naprowadzić młodego czytelnika na właściwe zrozumienie utworu ${ }^{35}$. Zapewne wiązało się to z powszechną praktyką przerabiania tekstów literackich "na ludowo", a więc podawaniu ich młodemu odbiorcy w formie streszczenia, jak praktykowano chociażby przy wspomnianej już serii „Arcydzieła Polskich i Obcych Pisarzy", gdzie właściwy utwór poprzedzało właśnie jego streszczenie. Na końcu tomu "Wyboru Pisarzów Polskich i Obcych dla Domu i Szkoły” umieszczano tzw. „przypisy”, które stanowiły komentarz edytorski. Utwór oczywiście opatrzony był u dołu objaśnieniami, zazwyczaj słownikowymi, frazeologicznymi, literackimi, niekiedy gramatycznymi, geograficznymi, historycznymi czy odwołującymi się do symboliki bądź tradycji, bądź religii. Ich język był komunikatywny i łatwy w odbiorze. Redaktorzy w przedmowie podkreślali, że celem było dostarczenie „Czytelnikom wyboru najlepszych utworów dawniejszych i nowszych pisarzów polskich, zaopatrzonych we wstępy, podające wskazówki, niezbędne dla należytego zrozumienia myśli i osnowy utworu, a także w objaśnienia wyrazowe i rzeczowe, zaznajamiające z przestarzałemi czy też mało znanemi formami języka i szczegółami faktecznemi”. Dodatkowo tom zawierający wybór poezji Horacego opatrzono Wykazem imion własnych.

Z kolei redaktorzy „Biblioteki Klasyków Polskich” - Konrad Drzewiecki i Andrzej Boleski - każdy tom opatrzyli tzw. „przypisami wydawcy”, również zamieszczonymi na końcu, zaraz po tekście, czyli: tabelą bio-bibliograficzną (tzw. kalendarium minimum) obejmującą fakty z życia autora, bez jakichkolwiek odwołań do literatury naukowej. W skład omawianych „przypisów” wchodził również, jak dzisiaj określilibyśmy, odpowiedni komentarz edytorski. Pod tekstem znajdowały się objaśnienia: literackie, filozoficzne, językowe, w tym gramatyczne (bardzo szczegółowe, bo wręcz podające dany przypadek odmiany czy deklinacji), frazeologiczne, słownikowe, historyczne, geograficzne, jak również tłumaczenia z języka łacińskiego i języków nowożytnych (np. włoskiego). Ich styl to niemalże literacka polszczyzna, ale komunikatywna i łatwa w odbiorze. Niewątpliwie takie objaśnienia przydawały się nie tylko uczniom, ale i dydaktykom. Natomiast zaraz po tekście danego dzieła literackiego umieszczano istotną z punktu edytorskiego wzmiankę, a mianowicie informację o jego pierwodruku.

Wyraźnie widać, jak różne były to wydawnictwa seryjne. Tomy w „Bibliotece Klasyków Polskich" wydawano bardziej starannie pod względem redakcyjno-edytorskim. Wydaje się, że znacznie lepiej przemawiały do młodego odbiorcy instruktywne, drobiazgowe i szczegółowe objaśnienia oraz krytyczny wstęp. Tym bardziej że rozwiązania redakcyjno-edytorskie, jakich dokonał Boleski, były kontynuowane, jak chociażby w przypadku pierwszego tomu, który objął wybór z dzieł Kochanowskiego: 21 pieśni (I 2, 5, 9; II 3, 9, 12, 19, 24; Czego chcesz od nas Panie..., Fragm. p. 4; Pieśni 110, 13; II 5, 13, 118; Fragm. Prze zdrowie gospodarz

${ }^{35}$ A. Baumfeld, O metodzie wykładu literatury polskiej III, „Nowe Tory” 1911, z. 3, s. 253. 
pije; Pijże Włódarzu...; Pieśni I 7, II 7; Fragm. p. 9; 22 fraszki i wybór z Psałterza (dedykacja, psalmy: 8, 23, 42, 46, 51, 70, 80, 91, 97, 104, 114, 127, 130, 137, 150). Boleski podał czytelnikowi cykl pieśni refleksyjnych, patriotycznych i sielskich, dokładnie ukazujący filozofię mistrza z Czarnolasu. Fraszki zaś tak dobrał, by ideowo odpowiadały wcześniej wskazanym pieśniom. Co ważne, układ ten wszedł wówczas do szkolnej dydaktyki literatury polskiej ${ }^{36}$. Powtórzył go także wydawca Kochanowskiego w „Wielkiej Bibliotece” Stanisław Adamczewski (1929, nr 134).

Warto podkreślić, że w 1921 roku Boleski i Drzewiecki podjęli się zainicjowania nowej serii wydawniczej „Arcydzieła Literatur Polskich i Obcych w Wyborze i Układzie dla Użytku Szkolnego”. W Warszawie w oficynie Jakuba Mortkowicza wyszedł jej jeden jedyny niestety zeszyt, który objął wybór z eposów homeryckich (Iliady i Odysei) w przekładach wybitnych twórców polskiej literatury: Kochanowskiego, Dmochowskiego, Słowackiego, Norwida, Siemińskiego, Mleczki, Rydla. Być może miało to być dopełnienie, może nawet kontynuacja „Biblioteki Klasyków Polskich", skoro objęła ona tylko twórców szesnasto- i siedemnastowiecznych.

Niewątpliwie redaktorom obu serii przyświecała idea popularyzacji dzieł poszczególnych autorów, ale i języka narodowego i trudnego w odbiorze języka staropolskiego. W tym tak trudnym okresie w dziejach Rzeczypospolitej nauczanie mowy ojczystej i historii oraz rodzima literatura były drogą do kształtowania świadomości narodowej. Wydawcom zależało więc na zapoznaniu młodzieży szkolnej z konkretnymi tekstami literackimi. Wśród wybranych do publikacji seryjnych autorów znaleźli się zarówno pisarze polscy, jak i obcy, począwszy od wieku XVI, a skończywszy na epoce romantyzmu. Redaktorzy podali do druku dzieła najwybitniejszych twórców epok dawnych (Jana Kochanowskiego, Mikołaja Reja, Sebastiana Klonowica, Łukasza Górnickiego, Mikołaja Sępa Szarzyńskiego, Andrzej Frycza Modrzewskiego, Szymona Szymonowica i Stanisława Orzechowskiego), oświecenia (Ignacego Krasickiego, Franciszka Zabłockiego i Alojzego Felińskiego) oraz narodowych wieszczów (Adam Mickiewicza, Juliusza Słowackiego i Zygmunta Krasińskiego). Ideą było pokazanie reprezentatywnych dzieł i twórców dla danej epoki. Redaktorzy skupili się także na przedrukowaniu literatury politycznej, w tym staropolskiej publicystyki i utworów romantycznych odnoszących się do powstania listopadowego. Zaprezentowali tych bohaterów literackich, którzy poświęcili się dla dobra ojczyzny. Postarali się o podanie szkolnemu odbiorcy tekstu wraz z omówieniem, właściwym komentarzem edytorskim i szczegółowymi objaśnieniami. Kierowali się przy tym wskazówkami metodycznymi i dydaktycznymi, które wcześniej jasno sformułowali. Kształtowali więc kulturę czytelniczą młodzieży szkolnej, co w przypadku wydawnictwa seryjnego jest znacznie trudniejsze. Kilkutomowym cyklem dzieł danego autora znacznie łatwiej zainteresować odbiorcę niż jednym poszczególnym tomem serii wydawniczej. Wyraźnie ingerowali w repertuar wydawniczy młodego odbiorcy. Na tle „Wyboru Pisarzów Polskich i Obcych dla Domu i Szkoły” „Biblioteka Klasyków Polskich” wypada znacznie

36 J. Starnawski, Andrzej Baumfeld-Boleski..., s. 90. 
lepiej, przede wszystkim pod względem przygotowania redakcyjno-edytorskiego. Ponadto jej redaktorzy pokusili się o prezentację trudnej literatury staropolskiej. Dzięki temu wydawnictwu seryjnemu wprowadzono w obieg czytelniczy pisarzy i dzieła, do lektury których młodzież szkolną byłoby zbyt trudno zachęcić, a opatrzeni stosownym komentarzem edytorskim i objaśnieniami oraz krótkim wprowadzeniem do lektury stali się na pewno dużo łatwiejsi w odbiorze i na pewno lepiej zrozumiani. Niemniej omawiane wydawnictwa seryjne spełniały jeszcze jedną, bardzo znaczącą funkcję, a mianowicie rejestrowały polski dorobek piśmienniczy w trudnym okresie dziejów Rzeczypospolitej i ratowały go przed rozproszeniem i niepamięcią ${ }^{37}$.

37 Por. J. Dybiec, Nie tylko szablą. Nauka i kultura polska w walce o utrzymanie tożsamości narodowej 1795-1918, Kraków 2004. 